\title{
Inhibition of herpes simplex virus DNA replication by ara-tubercidin
}

\author{
Steven R. Turk ${ }^{1}$, P. Dan Cook ${ }^{2, *}$, C. Michael Reinke ${ }^{1, * *}$, \\ and John C. Drach ${ }^{1}$ \\ 'Department of Oral Biology, School of Dentistry, The University of Michigan, Ann Arbor, \\ Michigan, U.S.A.; ${ }^{2}$ Warner-Lambert/Parke-Davis, Ann Arbor, Michigan, U.S.A.
}

(Received 24 February 1987; accepted 10 June 1987)

\section{Summary}

Preliminary studies of the biochemical basis for the antiviral activity of the pyrrolo[2,3-d]pyrimidine nucleoside ara-tubercidin were conducted. Herpes simplex virus DNA synthesis was 3-fold more sensitive to inhibition by ara-tubercidin than was cellular DNA synthesis. Partially purificd herpes DNA polymerases were more sensitive to inhibition by ara-tubercidin $5^{\prime}$-triphosphate than were cellular polymerases $\alpha$ and $\beta$. Inhibition of viral DNA polymerase was competitive with dATP and noncompetitive with dTTP. The results suggest that the viral DNA polymerase plays a significant role in the antiviral activity of ara-tubercidin.

Antiviral; Herpes, HSV; Nucleoside; Pyrrolopyrimidine; Ara-tubercidin

The pyrrolo[2,3- $d$ ]pyrimidine nucleosides are purine nucleoside analogs in which the nitrogen atom at position 7 of the heterocyclic base has been replaced by a carbon atom. In addition to possessing antineoplastic, antimicrobial, and antiparasitic activity (Ritch and Glazer, 1984), some of these compounds exhibit activity against a variety of RNA and DNA viruses. For example, tubercidin (Fig. 1), was shown by Acs et al. (1964) to inhibit the in vitro replication of vaccinia virus, reovirus, and mengovirus (a strain of murine encephalomyocarditis virus). The 5-

Correspondence to: J.C. Drach, Department of Oral Biology, School of Dentistry, The University of Michigan, Ann Arbor, MI 48109, U.S.A.

*Present address: Eastman Kodak Co., Research Laboratories, Rochester, NY 14650, U.S.A.

"* Present address: College of Pharmacy, Auburn University, Auburn, AL 36849, U.S.A. 


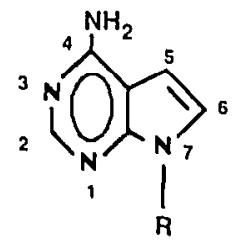

Fig. 1. Structure of (a) tubercidin $(R=$ ribose) and $(b)$ ara-tubercidin $(R=$ arabinose $)$.

bromo derivative of tubercidin is an inhibitor of SV-40 and Rous sarcoma virus replication (Brdar et al., 1973). More recently, a larger series of 5-substituted tubercidin analogs was found to possess activity against numerous viruses, including rhinoviruses (De Clercq et al., 1986) and herpes simplex virus types 1 and 2 (HSV1 and HSV-2) (Bergstrom et al., 1984). Although tubercidin and other ribosyl pyrrolopyrimidines effectively block virus replication, their associated cytotoxicity (Owen and Smith, 1964; Ritch and Glazer 1984; Suhadolnik, 1979) is far too great to permit consideration of these analogs as useful antiviral agents.

In contrast, pyrrolopyrimidine nucleosides containing sugars other than ribose have exhibited improved antiviral selectivity against herpes viruses. The carbocyclic analogs of arabinosyl and lyxosyl 7-deazaguanine, for example, were active against HSV -1 and $\mathrm{HSV}-2$ at concentrations lower than those necessary to produce significant cytotoxicity (Legraverend et al., 1985; Zerial et al., 1986). Similarly, De Clercq and coworkers (De Clercq et al., 1987; De Clercq and Robins, 1986) reported that xylotubercidin and other sugar-modified pyrrolopyrimidines possessed antiviral selectivity against HSV-1 and HSV-2 in vitro and in vivo.

We recently reported that certain arabinosyl and deoxyribosyl pyrrolo[2,3-d]pyrimidines are active and selective in vitro against both human cytomegalovirus (HCMV) and HSV-1 (Turk et al., 1987) Ara-sangivamycin, for example, produced three- and five-logarithmic reductions in HSV-1 and HCMV titers, respectively, at a concentration $(10 \mu \mathrm{M})$ approximating the $50 \%$ inhibitory $\left(\mathrm{I}_{50}\right)$ concentration for cellular cytotoxicity. We further found that viral DNA replication was inhibited by these compounds and hypothesized that this inhibition formed the basis for antiviral activity. In an initial examination of this hypothesis, we have examined the biochemical basis for the effects of the parent compound of this series (ara-tubercidin; Fig. 1) on the inhibition of viral DNA replication by herpes simplex viruses.

$\mathrm{KB}$ cells, an established human cell line derived from an epidermoid oral carcinoma, were used to propagate HSV-1 and HSV-2. Cells were routinely passaged in minimal essential medium (MEM) with Hank's salts supplemented with $10 \%$ calf serum. Monolayer cultures of cells were grown to confluency in $25-\mathrm{cm}^{2}$ flasks and used for virus titer (yield) reduction experiments as follows. Cultures were infected with the HF strain of HSV-1 (obtained from Dr. G.H. Cohen, University of Pennsylvania) at a multiplicity of infection of $5 \mathrm{PFU} /$ cell in $\mathrm{MEM}$ containing Earle's salts buffered with $25 \mathrm{mM}$ Hepes and supplemented with $5 \%$ serum and $0.127 \mathrm{~g} / \mathrm{l} \mathrm{L}$-arginine (virus growth medium (VGM)). Following a 1 -h incubation to 
permit virus adsorption, selected concentrations of ara-tubercidin in VGM were added and the cultures incubated for $18-24 \mathrm{~h}$ at $37^{\circ} \mathrm{C}$. The amount of infectious virus produced was quantitated as described previously (Shipman et al., 1976). Aratubercidin and its $5^{\prime}$-monophosphate were synthesized by one of us (P.D.C.) as described elsewhere (Cook, 1982). The monophosphate was converted to its $5^{\prime}$ triphosphate by the general method of Hoard and Ott (1965).

The results of titer reduction assays with HSV-1 indicated that production of infectious virus was inhibited by ara-tubercidin, albeit weakly. Individual $\mathrm{I}_{50}$ concentrations of $620 \mu \mathrm{M}$ (Turk et al., 1987) and $730 \mu \mathrm{M}$ were obtained in two separate experiments. Similarly, in a plaque reduction assay an $\mathrm{I}_{50}$ concentration of $320 \mu \mathrm{M}$ was obtained (Turk et al., 1987). In contrast, the known antiviral drug vidarabine (ara-A) (Buchanan and Hess, 1980) had an $I_{50}$ concentration of $2.1 \mu \mathrm{M}$ when assayed in the presence of an adenosine deaminase inhibitor (Schwartz et al., 1976). Thus, changing the purine ring system of vidarabine to the pyrrolo[2,3d]-pyrimidine ring system of ara-tubercidin decreased activity against HSV-1 $>300$ fold.

In an effort to elucidate the biochemical basis for the antiviral effect of ara-tubercidin, inhibition of cellular and viral DNA replication was examined as part of the titer reduction experiment which gave an $\mathrm{I}_{50}$ concentration of $620 \mu \mathrm{M}$. In that experiment $\left[{ }^{3} \mathrm{H}\right] \mathrm{dThd}(24 \mathrm{Ci} / \mathrm{mmol})$ was added to the cultures at a final concentration of $6 \mu \mathrm{M}(2 \mu \mathrm{Ci} / \mathrm{ml})$ concurrently with the test compound. After incubation and subsequent titration of virus, cells were harvested and viral DNA separated from cellular DNA by isopycnic centrifugation in $\mathrm{CsCl}$ gradients as previously described (Shipman et al., 1976). The results (not shown) indicated a modest preferential inhibition of HSV-1 DNA synthesis with respect to cellular DNA synthesis within the same infected cells. A comparison of $I_{50}$ concentrations, for instance, indicated that viral DNA synthesis was 3-fold more sensitive to inhibition than was the synthesis of cellular DNA $\left(\mathrm{I}_{50}\right.$ concentrations $=220 \mu \mathrm{M}$ (Turk et al., 1987) and $670 \mu \mathrm{M}$, respectively). This 3 -fold difference in sensitivity, while not large, is nearly identical in magnitude to that reported by Zerial et al. (1986) for a carbocyclic arabinosyl analog of 7-deazaguanosine, and by Schwartz et al. (1976) for the clinically useful drug vidarabine.

The mechanistic basis for the differential inhibition of viral and cellular DNA synthesis was investigated by measuring the effect of the $5^{\prime}$-triphosphate of aratubercidin (ara-tubercidin-TP) on partially purified DNA polymerases. The viral DNA polymerases specified by HSV -1 and HSV-2 and cellular DNA polymerases $\alpha$ and $\beta$ were isolated and assayed as described previously (Bennett et al., 1981; Reinke et al., 1978). Table 1 lists the inhibitory constants determined for ara-tubercidin-TP and illustrates that this compound was an effective inhibitor of the viral polymerases. To our knowledge, this is the first report of a herpesvirus DNA polymerase being inhibited by a pyrrolopyrimidine nucleotide. Furthermore, this compound selectively inhibited HSV-1 and HSV-2 polymerases with respect to cellular polymerases. Based on a comparison of $K_{i}$ concentrations, cellular polymerase $\alpha$ had approx. 5- and 15-fold less affinity for this inhibitor than did the respective viral polymerases. Cellular polymerase $\beta$ was not inhibited significantly 


\section{TABLE 1}

Kinetic constants for inhibition of HSV-induced and cellular DNA polymerases by ara-tubercidin $5{ }^{\prime}-$ triphosphate*.

\begin{tabular}{lr}
\hline DNA polymcrase & $K_{\mathrm{i}}(\mu \mathrm{M})$ \\
\hline HSV-1 & 17 \\
HSV-2 & 5 \\
$\alpha$ & 72 \\
$\beta$ & $>300$ \\
\hline
\end{tabular}

* Viral DNA polymerases were isolated from KB cells infected with either the HF strain of HSV-1 or the X-79 strain of HSV-2. Cellular DNA polymerases $\alpha$ and $\beta$ were isolated from uninfected KB cells. Polymerase activity was measured by quantitating the amount of $\left[{ }^{3} \mathrm{H}\right] \mathrm{dATP}$ incorporated into acid-insoluble material during a $15-\mathrm{min}$ incubation of the enzyme preparation with the appropriate reaction mixture. $K_{\mathrm{i}}$ concentrations were determined from analysis of Dixon plots (Dixon and Webb, 1979).

by this compound at the highest concentration tested. The preferential inhibition of viral DNA synthesis by ara-tubercidin therefore is a possible consequence of the preferential sensitivity of the viral DNA polymerase to ara-tubercidin-TP.

The manner in which viral DNA polymerases were inhibited by ara-tubercidinTP was investigated further using two different methods. (1) Analysis of kinetic data from inhibition studies with partially purified enzymes (data not shown) indicated that (a) inhibition of HSV-1 and HSV-2 polymerases was competitive with respect to dATP, and (b) inhibition of the HSV-2 enzyme was noncompetitive with respect to dTTP. The $K_{\mathrm{i}}$ concentration calculated from a Dixon plot of these data was $40 \mu \mathrm{M}$. (2) Viral DNA synthesis also was measured in nuclei isolated from HSV-2 infected cells. We previously have shown that this system provides a convenient in situ source of herpes DNA polymerase under conditions in which the natural replication complex remains intact (Barnett et al., 1984). In brief, monolayer cultures of KB cells were infected with the X-79 strain of HSV-2 (obtained from Dr. E.R. Kern, University of Utah) at a multiplicity of infection of 2 PFU/cell and harvested $9 \mathrm{~h}$ post-infection (Barnett et al., 1984). Nuclei were isolated and DNA synthesis measured by quantitating the amount of $\left[{ }^{3} \mathrm{H}\right] \mathrm{dATP}$ incorporated into acid-insoluble material. The Dixon plot presented in Fig. 2 confirms results obtained with partially purified enzymes by illustrating that inhibition of HSV-2 DNA polymerase activity by ara-tubercidin-TP was competitive with respect to dATP. The average $K_{i}$ concentration of ara-tubercidin-TP derived from two experiments was $16 \mu \mathrm{M}$ and was similar in magnitude to the value $(5 \mu \mathrm{M})$ obtained using the partially purified enzyme. In contrast, we previously reported that the $5^{\prime}$-triphosphate of vidarabine had a $K_{\mathrm{i}}$ concentration of $0.03 \mu \mathrm{M}$ in this system (Barnett et al., 1984). The $>500$-fold difference in potency is similar to that noted above in HSV-1 titer reduction experiments with these two compounds and further implicates the viral DNA polymerase as possessing a significant role in the antiviral activity of ara-tubercidin.

The results reported herein suggest additional studies which should be performed. For example, we have not eliminated the possibility that ara-tubercidin- 


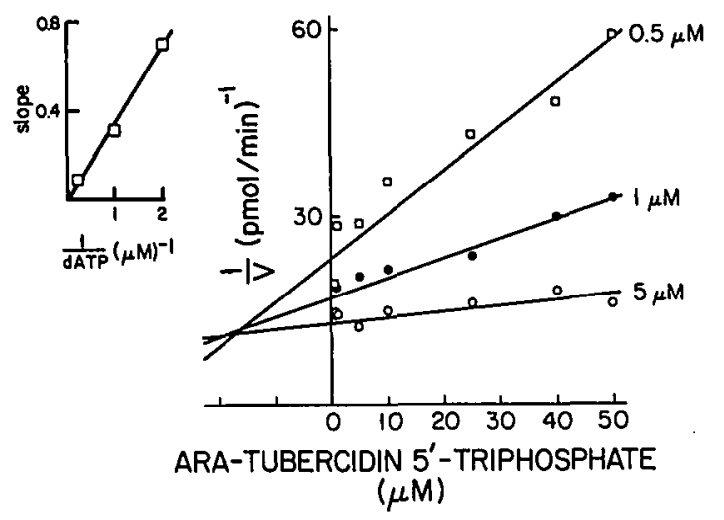

Fig. 2. Dixon plot of the inhibition by ara-tubercidin 5'-triphosphate of viral DNA synthesis in nuclei isolated from HSV-2-infected KB cells. Reaction mixtures included one of the three $\left[{ }^{3} \mathrm{H}\right] \mathrm{dATP}$ concentrations indicated. The common intersection of the regression lines above the $x$-axis indicates that inhibition is either competitive or mixed-type in manner (Dixon and Webb, 1979). A replot of the slopes (inset) passes through the origin, indicating that inhibition is competitive rather than mixed-type (Dixon and Webb, 1979).

TP acted as an alternate substrate which slowed elongation by the viral DNA polymerases. Furthermore, the hypothesis that inhibition of viral DNA polymerase accounted for the antiviral activity of ara-tubercidin is based on the assumption that ara-tubercidin was phosphorylated in situ to the active triphosphate metabolite. The fact that the $\mathrm{I}_{50}$ concentration of the nucleoside for inhibition of virus replication was significantly higher than the $K_{\mathrm{i}}$ concentration of the triphosphate for inhibition of viral DNA polymerase activity suggests that ara-tubercidin might be poorly phosphorylated in vitro. These and other questions must be answered before the mode of action of this nucleoside can be understood completely.

\section{Acknowledgements}

We thank Drs. C. Shipman, Jr. and J.W. Barnett for many helpful discussions and Sandra H. Smith and Gail Genzlinger for expert technical assistance. S.R.T. was supported in part by National Institutes of Health, National Research Service Award T32-GM-07767 from the University of Michigan. This project was supported in part with Federal funds from the Department of Health and Human Services under contract number NO1-AI-42554. The content of this publication does not necessarily reflect the views or policies of the Department of Health and Human Services, nor does mention of trade names, commercial products, or organizations imply endorsement by the U.S. Government. 


\section{References}

Acs, G., Reich, E. and Mori, M. (1964) Biological and biochemical properties of the analogue antibiotic tubercidin. Proc. Natl. Acad. Sci. U.S.A. 52, 493-501.

Barnett, J.W., Reinke, C.M., Turk, S.R. and Drach, J.C. (1984) DNA polymerase in nuclei isolated from herpes simplex virus type-2-infected cells. Characterization of the reaction product and inhibition by substrate analogs. Biochim. Biophys. Acta 781, 130-142.

Bennett, L.L., Jr., Allan, P.W., Shaddix, S.C., Shannon, W.H., Arnett, G., Westbrook, L., Drach, J.C. and Reinke, C.M. (1981) Biological activities and modes of action of 9- $\alpha$-D-arabinofuranosyladenine and 9- $\alpha$-D-arabinofuranosyl-8-azaadenine. Biochem. Pharmacol. 30, 2325-2332.

Bergstrom, D.E., Brattesani, A.J., Ogawa, M.K., Reddy, P.A., Schweickert, M.J., Balzarini, J. and De Clercq, E. (1984) Antiviral activity of C-5 substituted tubercidin analogues. J. Med. Chem. 27, 285-292.

Brdar, B., Rifkin, D.B. and Reich, E. (1973) Studies of Rous sarcoma virus. Effects of nucleoside analogues on virus synthesis. J. Biol. Chem. 248, 2397-2408.

Buchanan, R.A. and Hess, F. (1980) Vidarabine (Vira-A ${ }^{(1)}$ ): pharmacology and clinical experience. Pharmacol. Ther. 8, 143-171.

Cook, P.D. (1982) 7- $\beta$-D-Arabinofuranosyl-7H-pyrrolo[2,3- $d$ ]pyrimidine compounds useful as antiviral agents and pharmaceutical compositions containing the compounds. U.S. Patent 4,352,795.

De Clercq, E. and Robins, M.J. (1986) Xylotubercidin against herpes simplex virus type 2 in mice. Antimicrob. Agents Chemother. 30, 719-724.

De Clercq, E., Bernaerts, R., Bergstrom, D.E., Robins, M.J., Montgomery, J.A. and Holy, A. (1986) Antirhinovirus activity of purine nucleoside analogs. Antimicrob. Agents Chemother. 29, 482-487.

De Clercq, E., Balzarini, J., Madej, D., Hansske, F. and Robins, M.J. (1987) Synthesis and biological properties of sugar-modified analogues of the nucleoside antibiotics tubercidin, toyocamycin, sangivamycin, and formycin. J. Med. Chem. 30, 481-486.

Dixon, M. and Webb, E.C. (1979) Enzymes, 3rd edn. Academic Press, New York.

Hoard, D.E. and Ott, D.G. (1965) Conversion of mono- and oligo-deoxyribonucleotides to $5^{\prime}$-triphosphates. J. Am. Chem. Soc. 87, 1785-1788.

Legraverend, M., Ngongo-Tekam, R.-M.N., Bisagni, E. and Zerial, A. (1985) ( \pm )-2-Amino-3,4-dihydro-7-[2,3-dihydroxy-4-(hydroxymethyl)-1-cyclopentyl]-7H-pyrrolo[2,3- $d$ ] pyrimidin-4-ones: new carbocyclic analogues of 7-deazaguanosine with antiviral activity. J. Med. Chem. 28, 1477-1480.

Owen, S.P. and Smith, C.G. (1964) Cytotoxicity and antitumor properties of the abnormal nucleoside tubercidin. Cancer Chemother. Rep. 36, 19-22.

Reinke, C.M., Drach, J.C., Shipman, C., Jr. and Weissbach, A. (1978) Differential inhibition of mammalian DNA polymerases $\alpha, \beta$ and $\gamma$ and herpes simplex virus-induced DNA polymerase by the $5^{\prime}$ triphosphates of arabinosyladenine and arabinosylcytosine. In: Oncogenesis and Herpesviruses, III, part 2 (de The, G., Henle, W. and Rapp, F., eds.), pp. 999-1005. Int. Agency Res. Cancer, Lyon, France.

Ritch, P.S. and Glazer, R.I. (1984) Pyrrolo[2,3-d]pyrimidine nucleosides. In: Developments in Cancer Chemotherapy (Glazer, R.I., ed.), pp. 1-33. CRC Press, Boca Raton, Florida.

Schwartz, P.M., Shipman, C., Jr. and Drach, J.C. (1976) Antiviral activity of arabinosyladenine and arabinosylhypoxanthine in herpes simplex virus-infected $\mathrm{KB}$ cells: selective inhibition of viral deoxyribonucleic acid synthesis in the presence of an adenosine deaminase inhibitor. Antimicrob. Agents Chemother. 10, 64-74.

Shipman, C., Jr., Smith, S.H., Carlson, R.H. and Drach, J.C. (1976) Antiviral activity of arabinosyladenine and arabinosylhypoxanthine in herpes simplex virus-infected $\mathrm{KB}$ cells: selective inhibition of viral deoxyribonucleic acid synthesis in synchronized suspension cultures. Antimicrob. Agents Chemother. 9, 120-127.

Suhadolnik, R.J. (1979) Nucleosides as biological probes. John Wiley and Sons, New York.

Turk, S.R., Shipman, C., '3r. Nassiri, R., Genzlinger, G., Krawczyk, S.H., Townsend, L.B. and Drach, J.C. (1987) Pyrrolo[2,3-d]pyrimidine nucleosides as inhibitors of human cytomegalovirus. Antimicrob. Agents Chemother. 31, 544-550.

Zerial, A., Zerial, M., Legraverend, M. and Bisagni, E. (1986) Antiviral activities of 54.247-RP, a carbocyclic analog of 7-deazaguanosine, in cell cultures and animals. Ann. Inst. Pasteur/Virol. 137E, $317-325$. 